\title{
Focus on Mascarenes Endemic Plants with Specific Phytochemical Composition, Potent Antioxidant and Antiproliferative Properties
}

Nawraj Rummun ${ }^{1,2,3}$, Philippe Rondeau, ${ }^{4}$ Emmanuel Bourdon ${ }^{4}$, Elisabete Pires ${ }^{5}$, James McCullagh, Timothy D.W. Claridge ${ }^{5}$, Theeshan Bahorun ${ }^{2}$, Wen-Wu Li ${ }^{3^{*}}$, Vidushi S. Neergheen ${ }^{12^{*}}$

${ }^{1}$ Department of Health Sciences, Faculty of Science, University of Mauritius, Réduit, 80837, Republic of Mauritius. n.rajeevr10@gmail.com (NR); v.neergheen@uom.ac.mu (VSN)

${ }^{2}$ ANDI Centre of Excellence for Biomedical and Biomaterials Research, MSIRI Building, University of Mauritius, Réduit, 80837, Republic of Mauritius. tbahorun@uom.ac.mu (TB)

${ }^{3}$ School of Pharmacy and Bioengineering, Faculty of Medicine and Health Sciences, Thornburrow Drive, Stoke on Trent, ST4 7QB, Keele University, UK. w.li@keele.ac.uk (WWL)

${ }^{4}$ Université de La Réunion, INSERM, UMR 1188 Diabète athérothrombose Thérapies Réunion Océan Indien (DéTROI), Saint-Denis de La Réunion, France. rophil@univ-reunion.fr (PR) ; emmanuel.bourdon@univreunion.fr $(\mathrm{EB})$

${ }^{5}$ Chemical Research Laboratory, University of Oxford, Oxford, OX1 3TA, United Kingdom. elisabete.pires@chem.ox.ac.uk (EP); james.mccullagh@chem.ox.ac.uk (JM); tim.claridge@chem.ox.ac.uk (TC)

*Correspondence: v.neergheen@uom.ac.mu (VSN); w.li@keele.ac.uk (WWL)

\begin{abstract}
Tropical forests constitute prolific sanctuary of unique floral diversity and potential medicinal sources, however, many of them remains unexplored. Herein, seven Mascarene endemic plants leaves were extracted and evaluated for their in vitro antioxidant properties and antiproliferative effects on a panel of cancer cell lines using MTT and clonogenic cell survival assay. Flow cytometry and comet assay were used to investigate the cell cycle and DNA damaging effects, respectively. Bioassay guided-fractionation coupled with LC-Mass spectrometry (MS), gas chromatography-MS, and nuclear magnetic resonance spectroscopy analysis were used to identify the bioactive compounds. Among the seven plants tested, Terminalia bentzoë was comparatively the most potent antioxidant extract with significantly $(\mathrm{p}<0.05)$ higher cytotoxic activities. T. bentzoë extract further selectively suppressed the growth of human hepatocellular carcinoma cells and significantly halted the cell cycle progression in G0/G1 phase, decreased the cells replicative potential and induced significant DNA damage. Ten phenolic compounds including punicalagin and ellagic acid were identified and likely contributed to the extract potent antioxidant and cytotoxic activities. These results established a promising basis for further in-depth investigations on the potential use of $T$. bentzoë as supportive therapy in cancer management.
\end{abstract}

Keywords: Terminalia bentzoë; Mascarene endemic; cytotoxicity; antioxidant; cell cycle arrest; phenolics; bioassay-guided fractionation

\section{Introduction}

The plant kingdom is known to be a prolific sanctuary of phytochemicals with unique therapeutic potential. At least $25 \%$ of the 1562 clinical drugs approved by the US Food and Drugs Administration are known to have been emanated from terrestrial plants [1,2]. Moreover, an estimate of about 28187 plant taxa, globally, are documented to have medicinal values with over 3000 species reported with the ethnomedicinal application against cancer [3,4]. The continued dependence of mankind on plants was further evidenced during the recent outbreak of the COVID-19 pandemic whereby, herbal medicines were used in an attempt to mitigate the symptoms of the novel coronavirus infection [57]. 
Madagascar and its neighbouring islands in the Western Indian Ocean regions are known as biodiversity hotspots [8]. Undoubtedly, untapped endemic plant species from these niche areas broadened the structural variation of novel chemotypes [9,10]. The tropical forest of Madagascar was once acknowledged as a fertile source of economically valuable plants with pharmacologically active ingredients [11]. Indeed, the anticancer drugs vinblastine and vincristine were derived from the Madagascan endemic Catharanthus roseus (Apocynaceae) [12]. Certainly, the market value of vincristine alone was estimated to be 15 million USD per kilogram, in the year 2016 [13].

Phytogeography investigations revealed that the Mascarene endemic plants islands have their ancestral lineages traced back from Madagascar [14]. As such, the unique floral biodiversity of Mauritius is expected to possess similar medicinal and therapeutic prolificacy as the Madagascan rain forest. However, instead of conserving such valuable biodiversity, human activities are pushing endemic taxa towards an unprecedented extinction crisis. In less than 400 years of human settlement, Mauritius has witnessed the shrinking of its native forest to around $5 \%$ of the original cover, leading to the permanent loss of $30(10.9 \%)$ of its endemic plant species and driving $81.7 \%$ of the remnant endemic taxa on the brink of extinction [15-17]. Nevertheless, the remnant areas of the pristine forest are still home to a plethora of endemic flora rich in high genetic diversity representing interesting sources for complementary and alternative medicine, nutraceuticals as well as pharmaceutical leads [16].

With this in mind, the in vitro antioxidant propensities of leaf extracts from seven plants endemic to Mascarene islands were investigated. The plants under study have documented traditional uses against ailments ranging from dermatological conditions, asthma to infectious diseases (Table 1). The cytotoxic effect of Terminalia bentzoë, on a panel of cancer cell lines, and its ability to impede the cell cycle progression in hepatocellular carcinoma (HepG2) cells were determined. The bioactive constituents in T. bentzoë leaf extract were characterised following bioassay-guided fractionation.

\section{Materials and Methods}

2.1. Plant material and preparation of total extracts.

Healthy fresh leaves of seven Mascarene endemic plants were collected in Mauritius and deposited at the Mauritius herbarium, where plant species were authenticated by the botanist (Table 1). The leaves were air-dried followed by exhaustive maceration with aqueous methanol (80 \%, v/v) and freeze-dried as described previously [18]. The assay results were expressed in terms of the lyophilised weight of extracts.

2.2. Estimation of polyphenolic contents.

The total phenolic, flavonoid, and proanthocyanidin level in the crude extracts were estimated using the Folin-Ciocalteu assay, aluminium chloride assay and $\mathrm{HCl} /$ Butan-1-ol assay as described [18].

2.3. In-vitro antioxidant capacities of extracts.

The antioxidant potential of the extracts was investigated according to reported methods [18,19]. The final reaction volume of $3.4 \mathrm{~mL}$ of the ferric reducing antioxidant power assay contained $100 \mu \mathrm{L}$ of extract and $300 \mu \mathrm{L}$ of water followed by addition of $3 \mathrm{~mL}$ FRAP reagent. The FRAP reagent was prepared immediately before use by mixing $100 \mathrm{~mL}$ of $0.25 \mathrm{M}$ acetate buffer (pH 3.6), $10 \mathrm{ml}$ of $20 \mathrm{mM}$ ferric chloride (source of $\mathrm{Fe}^{3}+$ ) and $10 \mathrm{~mL}$ of $10 \mathrm{mM} \mathrm{2,4,6-tripyridyl-s-triazine.} \mathrm{After} \mathrm{incubating} \mathrm{the}$ mixture for 4 minutes at ambient temperature, the absorbance was read at $593 \mathrm{~nm}$ against a blank. 
Table 1: The investigated Mascarene endemic plant species.

\begin{tabular}{|c|c|c|c|c|c|c|c|}
\hline Species & Family & $\begin{array}{l}\text { Vernacular } \\
\text { names }\end{array}$ & $\begin{array}{l}\text { Ethnomedicinal uses } \\
{[16]}\end{array}$ & Collection site & Collection date & $\begin{array}{l}\text { Mauritius } \\
\text { herbarium } \\
\text { accession } \\
\text { code }\end{array}$ & $\%$ Yield \\
\hline $\begin{array}{l}\text { Antirhea borbonica } \\
\text { J.F.Gmel }\end{array}$ & Rubiaceae & $\begin{array}{l}\text { Bois } \\
\text { lousteau, } \\
\text { Bois } \\
\text { d'oiseau }\end{array}$ & $\begin{array}{l}\text { Astringent, diarrhoea, } \\
\text { dysentery, stop } \\
\text { bleeding, promote } \\
\text { wound repair, skin } \\
\text { diseases, tambave, } \\
\text { Urinary tract } \\
\text { infections }\end{array}$ & $\begin{array}{l}\text { Gaulettes } \\
\text { Serrées }\end{array}$ & 14-Oct-2014 & $\begin{array}{l}\text { MAU } \\
0009462\end{array}$ & 5.53 \\
\hline $\begin{array}{l}\text { Dictyosperma album } \\
\text { (Bory) H. Wendl. \& } \\
\text { Drude ex Scheff var. } \\
\text { conjugatum H. E. Moore } \\
\text { \& Guého }\end{array}$ & Arecaceae & $\begin{array}{l}\text { Palmiste } \\
\text { blanc }\end{array}$ & Not described & $\begin{array}{l}\text { Réduit, Joseph } \\
\text { Guého } \\
\text { Arboretum }\end{array}$ & 19-Aug-2014 & $\begin{array}{l}\text { MAU } \\
0016674\end{array}$ & 8.52 \\
\hline $\begin{array}{l}\text { Erythroxylum } \\
\text { sideroxyloides Lam }\end{array}$ & Erythroxylaceae & $\begin{array}{l}\text { Bois de } \\
\text { ronde }\end{array}$ & Renal stones & $\begin{array}{l}\text { Lower Gorges } \\
\text { National Park, } \\
\text { 'Morne Sec' }\end{array}$ & 15-Oct-2014 & $\begin{array}{l}\text { MAU } \\
0016542\end{array}$ & 13.81 \\
\hline Ficus mauritiana Lam & Moraceae & $\begin{array}{l}\text { Figuier } \mathrm{du} \\
\text { pays }\end{array}$ & Not described & $\begin{array}{l}\text { Gaulettes } \\
\text { Serrées }\end{array}$ & 14-Nov-2014 & $\begin{array}{l}\text { MAU } \\
0011002\end{array}$ & 3.10 \\
\hline $\begin{array}{l}\text { Hancea integrifolia } \\
\text { (Willd.) S.E.C. Sierra, } \\
\text { Kulju \& Welzen }\end{array}$ & Euphorbiaceae & Bois pigeon & $\begin{array}{l}\text { Clean the blood and } \\
\text { improve blood } \\
\text { circulation, tonic. }\end{array}$ & $\begin{array}{l}\text { Gaulettes } \\
\text { Serrées }\end{array}$ & 14-Nov-2014 & $\begin{array}{l}\text { MAU } \\
0016431\end{array}$ & 10.42 \\
\hline
\end{tabular}

(n)




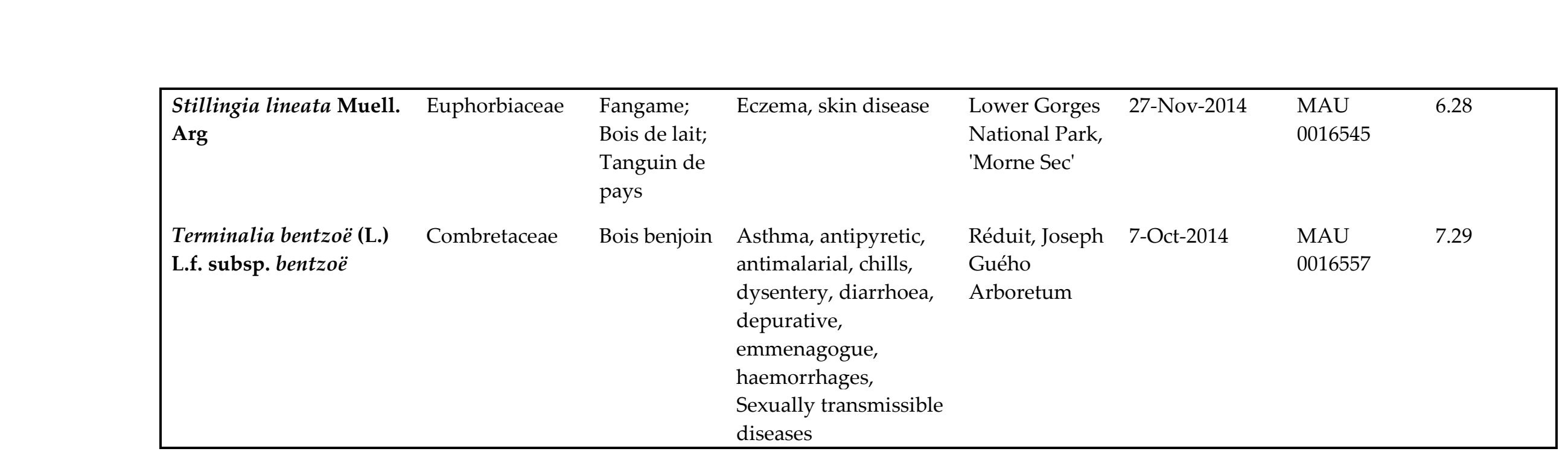 \\ doi:10.20944/preprints202009.0094.v1}

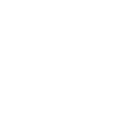


The DPPH assay protocol involved mixing varying concentrations of $100 \mu \mathrm{L}$ of the methanolic extract with $200 \mu \mathrm{L}$ of $100 \mu \mathrm{M}$ methanolic DPPH and absorbance were read 30 minutes post-incubation at ambient temperature.

The reaction mixture for iron-chelating activity contained $40 \mu \mathrm{L}$ of plant extract (concentrations ranging between 0 to $10 \mathrm{mg} / \mathrm{ml}), 10 \mu \mathrm{L}$ of $\mathrm{FeCl}_{2} \cdot 4 \mathrm{H}_{2} \mathrm{O}(0.5 \mathrm{mM})$ and $150 \mu \mathrm{L}$ of distilled deionized water. The mixture was incubated at ambient temperature for 5 minutes, before the addition of $10 \mu \mathrm{l}$ of ferrozine $(2.5 \mathrm{mM})$ and the absorbance was read at $562 \mathrm{~nm}$. The final $250 \mu \mathrm{L}$ reaction volume for superoxide anion scavenging assay contained $25 \mu \mathrm{L}$ of plant extract $(0$ to $300 \mu \mathrm{g} / \mathrm{mL}), 100 \mu \mathrm{L}$ of 156 $\mu \mathrm{M}$ of nitroblue tetrazolium and $100 \mu \mathrm{L}$ of $200 \mu \mathrm{M}$ beta-nicotinamide adenine dinucleotide reduced disodium salt hydrate and $30 \mu \mathrm{L}$ of phenazine methosulphate. The absorbance was read at $560 \mathrm{~nm}$ following 30 minutes incubation at $25{ }^{\circ} \mathrm{C}$.

The nitric oxide radical scavenging activity was conducted in a 96-well plate. $50 \mu \mathrm{L}$ of aqueous extract ( 0 to $100 \mu \mathrm{g} / \mathrm{ml}$ ) and $100 \mu \mathrm{L}$ of $5 \mathrm{mM}$ of sodium nitroprusside (in phosphate saline buffer, $\mathrm{pH} 7.4$ ) was incubated at $25{ }^{\circ} \mathrm{C}$ for 150 minutes. After incubation, $125 \mu \mathrm{L}$ of the reaction mixture was transferred to another 96- well plate, to which $100 \mu \mathrm{L}$ of $0.33 \%$ sulfanilic acid in $20 \%$ glacial acetic acid was added. After 5 minutes, $100 \mu \mathrm{L}$ of $0.1 \%$ of N-1-napthyethylenediamine dihydrochloride was added and the pink coloration formed was read at $546 \mathrm{~nm}$.

The deoxyribose degradation inhibitory assay protocol was optimised to a 24 well microtiter plate format. Each well contained $50 \mu \mathrm{L}$ of aqueous extract, $50 \mu \mathrm{L}$ of $1 \mathrm{mM}$ EDTA, $100 \mu \mathrm{L}$ of $500 \mu \mathrm{M} \mathrm{FeCl}$, $50 \mu \mathrm{L}$ of $1 \mathrm{mM}$ ascorbic acid, $50 \mu \mathrm{L}$ of $10 \mathrm{mM}$ hydrogen peroxide, $100 \mu \mathrm{L}$ of $100 \mathrm{mM} \mathrm{KH}_{2} \mathrm{PO}_{4}-\mathrm{KOH}$ buffer (pH 7.4) and $100 \mu \mathrm{L}$ of $15 \mathrm{mM}$ 2-deoxyribose. The reaction mixture was incubated at $37^{\circ} \mathrm{C}$ for 90 minutes. At the end of the incubation period, $500 \mu \mathrm{L}$ of $10 \%(\mathrm{w} / \mathrm{v})$ trichloroacetic acid followed by $500 \mu \mathrm{L}$ of $1 \%(\mathrm{w} / \mathrm{v})$ thiobarbituric acid were added to each well and the solutions were heated in a water bath at $80{ }^{\circ} \mathrm{C}$ for 20 minutes to develop the pink chromogen. The absorbance of the reaction mixture was read both before and after incubation at $80{ }^{\circ} \mathrm{C}$. Results were given in mg lyophilised extract $/ \mathrm{mL}$.

Extract vehicle and gallic acid (or otherwise stated) were used as negative and positive controls respectively. The percentage activity of the extracts was calculated relative to the negative control. GraphPad Prism 6 software (GraphPad Inc., USA) was used to plot the dose-response curves and to generate the half-maximal inhibitory concentration $\left(I C_{50}\right)$ values. All experiments were performed in triplicates in three independent assays. The results were expressed as mean $\pm \mathrm{SEM}$.

\subsection{Human cell lines and culture conditions.}

Human liposarcoma cells (SW872), Human lung carcinoma cells (A549) and Human hepatocellular carcinoma cells (HepG2), human ovarian carcinoma cell lines OVCAR-4 and OVCAR-8 were purchased from American Type Culture Collection (USA). Human ovarian epithelial (HOE) cells immortalized using SV40 large T antigen was obtained from Applied Biological Materials Inc (Canada). All cell lines, except the ovarian cell lines, were cultured in Dulbecco's Modified Eagle's Medium. Roswell Park Memorial Institute (RPMI) 1640 medium was used in the case of ovarian cell lines. Culture medium was supplemented with $10 \%$ fetal bovine serum, $2 \mathrm{mM}$ L-glutamine and 100 $\mathrm{U} / \mathrm{L}$ streptomycin-penicillin. Cells were grown in a humidified atmosphere of $5 \%$ carbon dioxide and $95 \%$ humidity at $37^{\circ} \mathrm{C}$.

\subsection{Cell-based assays.}

The viability of the investigated cells treated with test samples was evaluated using the methyl thiazolyl diphenyl-tetrazolium bromide (MTT) cell viability assay. Following overnight acclimatisation of cells in 96-well plate, cells were treated with test samples for 48 hours and assayed for different parameters. For 96-well plate, the seeding densities for cancer cell lines and HOE cells were $5 \times 10^{3}$ cells and $2 \times 10^{3}$ cells per well, respectively. All experiments were performed in triplicates (unless otherwise specified) in three independent assays. 


\subsubsection{MTT viability assay}

The MTT assay was performed as previously described [20]. The percentage cell viability relative to DMSO control $\left(0.025 \% \mathrm{v} / \mathrm{v}\right.$, final concentration) was calculated and the $I C_{50}$ value determined using GraphPad Prism 6 software (GraphPad Inc., USA).

\subsubsection{Clonogenic cell survival assay}

The effect of T. bentzoë leaf extract on the cell reproductive death was assessed by clonogenic cell survival assay according to reported methods, with slight modifications (Al-Dabbagh et al., 2018; Franken et al., 2006). HepG2 cells were seeded in a 6-well plate (500/well) and allowed to attach overnight. Following 48 hours treatment period with extract/ control, the media was replaced with fresh complete culture media and cells were grown under standard recommended culture conditions for an additional 7 days to allow large colonies formation. Colonies were then fixed with $4 \%$ paraformaldehyde for 30 minutes and stained with $0.5 \%(\mathrm{w} / \mathrm{v})$ crystal violet. The individual wells were imaged using a digital camera and the colonies counted using ImageJ software (the US, National Institute of Health). The cytotoxic effect was expressed as the percentage of surviving colonies relative to untreated control.

\subsubsection{Single Cell Gel Electrophoresis}

Comet assay was carried out according to the method described [21,22] with minor modifications. Briefly, $30 \mu \mathrm{L}$ of pre-treated cells were mixed with $70 \mu \mathrm{L}$ of $1 \%(\mathrm{w} / \mathrm{v})$ low melting agarose (LMA) and $40 \mu \mathrm{L}$ of the cell-LMA mixture was placed on frosted microscope slides pre-coated with $1.5 \%$ normal melting agarose. A coverslip was placed on top of the cell-LMA mix and allowed to solidify at $4^{\circ} \mathrm{C}$ for 1 hour in dark. Following solidification, the coverslip was gently slid off and the slides were immersed in pre-chilled lysis buffer $(2.5 \mathrm{M} \mathrm{NaCl}, 0.1 \mathrm{M}$ EDTA, $10 \mathrm{mM}$ Tris base, $1 \% \mathrm{v} / \mathrm{v}$ Triton $\mathrm{X}-100$ (added 30 minutes before use), $\mathrm{pH} 10,4^{\circ} \mathrm{C}$ ) for 1 hour in dark. Following this period, the excess lysis solution was drained and the slides were submerged in electrophoresis buffer $(0.2 \mathrm{M} \mathrm{NaOH}$, 1 mM EDTA, $\mathrm{pH} 13,4^{\circ} \mathrm{C}$ ) for 30 minutes in dark, to allow the DNA to unwind.

Electrophoresis was conducted for 30 minutes at 30 volts and $350 \mathrm{~mA}$. The gels were neutralized by immersing in pre-chilled neutralisation buffer $\left(0.4\right.$ Tris-HCL, $\left.\mathrm{pH} 7.5,4^{\circ} \mathrm{C}\right)$ for 10 minutes in dark. The slides were washed in distilled water, fixed with $4 \%$ formalin solution for 20 minutes and allowed to air-dry overnight. The slides were stained with Hoechst $33342(1 \mu \mathrm{g} / \mathrm{ml})$, air-dried in dark and visualised at $200 \mathrm{X}$ magnification in DAPI, using EVOS fluorescence microscope (Life Technologies). Damaged DNA was measured for 100 randomly selected cells (for each independent experiment) using the Comet Assay IV 4.3.1 (Perceptive instrument, UK).

\subsubsection{Flow cytometric analysis}

Apoptosis/necrosis analysis was performed on HepG2 cells after 48 hours treatment by flow cytometry (Beckman Coulter's CytoFLEX and Cytexpert software) using Annexin V-FITC and Propidium iodide (PI) double staining as described in a previous study [23]. Cell cycle analysis was performed using propidium iodide for DNA staining as described [24]. Percentage of cells in different phases (Go/G1, S and $\mathrm{G}_{2} \mathrm{M}$ phases) were quantified from propidium iodide fluorescence intensityarea (PI-A) histograms corresponding to the DNA content of HepG2 cells.

\subsubsection{MTT-guided fractionation and identification of bioactive molecules}

The total extract of T. bentzoë was solubilised in distilled water and sequentially partitioned with ethyl acetate, followed by n-butanol. Each fraction was dried and their cytotoxicity evaluated against SW872, A549, HepG2 using the MTT cell viability assay. The butanol fraction being selective towards HepG2 cells was subjected to Sephadex LH-20 column chromatography $(30 \mathrm{~cm}$ X $2.1 \mathrm{~cm}$ internal diameter) and eluted with water, water: methanol $(3: 1 \mathrm{v} / \mathrm{v}, 1: 1 \mathrm{v} / \mathrm{v}$ and $1: 3 \mathrm{v} / \mathrm{v}$ respectively), methanol and acetone. The flow rate was maintained at $1.5 \mathrm{~mL} / \mathrm{min}$. Guided by the cytotoxicity against HepG2 
cells and purity profile, potent sub-fraction was further fractionated using semi-preparative HPLC column. The crude extract and thereof derived purified fractions were analysed by extensive spectroscopic methods including GC-MS, LC-MS, HPLC, ${ }^{1} \mathrm{H}-\mathrm{NMR}$ and ${ }^{13} \mathrm{C}-\mathrm{NMR}$ (Supporting Information). For analytical HPLC, the concentration of standards in the crude extract was determined from the linear regression of the analytical standards curve namely $y=12.317 \mathrm{x}, \mathrm{R}^{2}=$ 0.9996: gallic acid and $y=16.066 x, R^{2}=0.9992$ : methyl gallate.

\subsection{STATISTICAL ANALYSIS}

Statistical analyses were performed using GraphPad Prism 6 software (GraphPad Inc., San Diego, California). The mean values among extracts were compared using One-Way ANOVA. Student t-test and/or Tukey's multiple comparisons as Post Hoc test was used to determine significances in mean phytochemicals, antioxidants and cytotoxic activities among different species. All charts were generated using Microsoft Excel software (version 2010).

\section{Results}

\subsection{Estimation of polyphenols level in the investigated leaf extracts.}

The phenolic content varied significantly among the seven leaf extracts under study $(\mathrm{p}<0.05)$ with amounts ranging between $70.2 \pm 4.72 \mathrm{mg}$ and $385 \pm 24.1 \mathrm{mg}$ gallic acid equivalent/g. Total flavonoid levels ranged between $2.43 \pm 0.06 \mathrm{mg}$ and $12.9 \pm 0.45 \mathrm{mg}$ quercetin equivalent/g. Based on the spectrophotometric assay results, the estimated level of phenolics and flavonoids were significantly highest $(\mathrm{p}<0.05)$ in $T$. bentzoë leaf extract as compared to the other investigated leaf extracts (Table 2). While the proanthocyanidin content prevailed in E. sideroxyloides leaf, both S. lineata leaf and $T$. bentzoë leaf had a remarkably negligible amount of proanthocyanidin detected by the butanol/ $\mathrm{HCl}$ assay.

\subsection{In-vitro antioxidant activities of the investigated leaf extracts.}

An array of five analytical models was used to benchmark the antioxidant potential of the investigated leaf extracts. The Mascarene endemic plant leaf extracts exhibited a varying degree of activities in the different antioxidant assays. All extracts showed a dose-dependent metal chelating and free radical scavenging activity (Table 2). In terms of iron chelation, all the extracts were weak chelator compared to EDTA with an $I C_{50}$ value of $0.01 \pm 0.00 \mathrm{mg} / \mathrm{mL}(23.6 \pm 0.22 \mu \mathrm{M})(\mathrm{p} \leq 0.05)$. As depicted in Table 2, among the seven accessions of plants, $T$. bentzoë showed the most effective antioxidant potential in all the five antioxidant assays. Thus, the free radical quenching activity of $T$. bentzoё was further evaluated in hydroxyl radical scavenging assay. T. bentzoë $\left(I C_{50}=0.25 \pm 0.03\right.$ $\mathrm{mg} / \mathrm{mL})$ exhibited a significantly $(\mathrm{p}<0.0001)$ greater degree of protection against Fenton-mediated oxidative damage to 2-deoxyribose sugar moiety as compared to gallic acid $\left(I C_{50}=1.65 \pm 0.09 \mathrm{mg} / \mathrm{mL}\right.$ ). 
Table 2: Phenolic content and antioxidant potential of investigated leaf extracts.

\begin{tabular}{|c|c|c|c|c|c|c|c|c|}
\hline Extract & $\begin{array}{l}\text { Total } \\
\text { phenolics } 1\end{array}$ & $\begin{array}{l}\text { Total } \\
\text { flavonoids }{ }^{2}\end{array}$ & $\begin{array}{l}\text { Total } \\
\text { proanthocya } \\
\text { nidins }^{3}\end{array}$ & FRAP $^{4}$ & $\begin{array}{l}\text { Iron } \\
\text { chelating } \\
\text { activity }^{5}\end{array}$ & $\begin{array}{l}\text { DPPH } \\
\text { Scavenging } \\
\text { activity }^{6}\end{array}$ & $\begin{array}{l}\text { Superoxide } \\
\text { scavenging } \\
\text { activity }^{6}\end{array}$ & $\begin{array}{l}\text { Nitric oxide } \\
\text { scavenging } \\
\text { activity }^{6}\end{array}$ \\
\hline A. borbonica & $70.2 \pm 4.72^{\mathrm{e}}$ & $3.15 \pm 0.07^{\mathrm{d}, \mathrm{e}}$ & $5.71 \pm 0.09 \mathrm{e}$ & $3.32 \pm 0.16^{\mathrm{d}, \mathrm{e}^{* * * * * *}}$ & $4.05 \pm 0.26^{b, c, c^{* * * * * *}}$ & $11.2 \pm 1.63^{\mathrm{d}^{* * * * * *}}$ & $19.0 \pm 2.46^{\mathrm{d}} \mathrm{d}^{* * * * *}$ & $80.3 \pm 29.0^{\mathrm{b}^{\text {,** }}}$ \\
\hline D. album & $75.7 \pm 5.22^{\mathrm{d}}$ & $2.43 \pm 0.06^{\mathrm{f}}$ & $30.9 \pm 0.58^{c}$ & $2.21 \pm 0.05^{\mathrm{e}^{* * * * *}}$ & $4.83 \pm 1.49 \mathrm{c}, \mathrm{d}$ & $7.89 \pm 0.13^{\mathrm{c}, * * * *}$ & 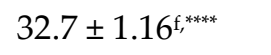 & $68.0 \pm 10.0^{a^{a}, *}$ \\
\hline $\begin{array}{l}\text { E. } \\
\text { sideroxyloides }\end{array}$ & $182 \pm 10.5^{\mathrm{b}}$ & $3.62 \pm 0.13^{d}$ & $121 \pm 3.25^{\mathrm{a}}$ & $9.14 \pm 0.85^{b^{* * * * *}}$ & $1.46 \pm 0.02^{\mathrm{a}^{* * * * * *}}$ & $4.44 \pm 0.26^{\mathrm{b}^{, * * * * *}}$ & $12.7 \pm 0.65^{c^{* * * * * *}}$ & $24.3 \pm 1.39^{a}$ \\
\hline F. mauritiana & $133 \pm 2.36^{c}$ & $10.4 \pm 0.21^{\mathrm{b}}$ & $85.7 \pm 2.38^{b}$ & $5.38 \pm 0.01 c^{* * * * * *}$ & $0.43 \pm 0.01 \mathrm{a}^{* * * * * *}$ & $5.35 \pm 0.23^{b}, * * * *$ & $24.2 \pm 0.44^{\mathrm{e}^{* * * * * *}}$ & $87.08 \pm 28.9^{b}, * * *$ \\
\hline H. integrifolia & $142 \pm 4.91^{c}$ & $2.75 \pm 0.06^{e, f}$ & $18.4 \pm 0.78^{d}$ & $9.37 \pm 0.29 b^{* * * * * *}$ & $0.78 \pm 0.01^{\mathrm{a}^{* * * * *}}$ & $4.16 \pm 0.16^{\mathrm{b}, * * * *}$ & $9.55 \pm 0.78^{b^{, * w+4}}$ & $68.49 \pm 37.5^{\mathrm{a}, \mathrm{b}, * *}$ \\
\hline S. lineata & $97.7 \pm 3.36^{d}$ & $6.61 \pm 0.19 c$ & ND & $4.53 \pm 0.02^{c, d^{* * * * * *}}$ & $6.45 \pm 0.02 \mathrm{~d}^{*}$ & $4.04 \pm 0.17 \mathrm{a}, \mathrm{b}, * * * * *$ & $3.81 \pm 0.48^{\mathrm{a}}$ & $68.5 \pm 42.9 \mathrm{~b}$, \\
\hline T. bentzoё & $385 \pm 24.1^{\mathrm{a}}$ & $12.9 \pm 0.45^{\mathrm{a}}$ & ND & $18.2 \pm 0.01^{\mathrm{a}^{* * * * * *}}$ & $0.10 \pm 0.00^{a^{* * * * * *}}$ & $2.65 \pm 0.14^{\mathrm{a}^{* *+*+}}$ & $5.20 \pm 0.53^{a}$ & $9.74 \pm 3.13^{a}$ \\
\hline Gallic acid & - & - & - & $24.8 \pm 0.22$ & $\begin{array}{l}8.00 \pm 0.04 \\
(47.0 \pm 0.23 \mathrm{mM})\end{array}$ & $\begin{array}{l}0.62 \pm 0.05 \\
(4.18 \pm 0.32 \mu \mathrm{M})\end{array}$ & $\begin{array}{l}5.52 \pm 0.11 \\
(31.4 \pm 0.84 \mu \mathrm{M})\end{array}$ & $\begin{array}{l}9.61 \pm 1.75 \\
(68.0 \pm 13.9 \mu \mathrm{M})\end{array}$ \\
\hline
\end{tabular}

${ }^{1}$ Values are expressed as $\mathrm{mg}$ of gallic acid equivalent (GAE)/g, ${ }^{2}$ values are expressed as mg of quercetin equivalent $(\mathrm{QE}) / \mathrm{g} ;{ }^{3} \mathrm{Values}$ are expressed as mg of cyanidin chloride equivalent (CCE)/g; ${ }^{4}$ Values are expressed in $\mathrm{mmol} \mathrm{Fe}{ }^{2+} ;{ }^{5} I_{50}$ values are expressed in $\mathrm{mg} / \mathrm{ml} ;{ }^{6} I C_{50} \mathrm{values}$ are expressed in $\mu \mathrm{g} / \mathrm{ml} ;$ Data represent mean \pm standard error of mean $(n=3)$. $N D=$ Not detected. Different letters between rows in each column represent significant differences between extracts $(p<0.05)$. Asterisks represent significant differences between extracts and gallic acid (positive control), ${ }^{*} p \leq 0.05,{ }^{* * *} p \leq 0.01,{ }^{* * *} p \leq 0.001,{ }^{* * * *} p \leq$ 0.0001 


\subsection{Effect of T. bentzoë leaf extract on cell survival.}

To assess the antiproliferative properties of T. bentzoë leaf extract on cancer cells, first, the influence of the extracts on the cell viability of five cancer cell lines notably, SW872, A549, HepG2, Ovcar-4 and Ovcar- 8 cells, were investigated using the MTT assay. T. bentzoë suppressed the growth of all cancer cell lines in a dose-dependent manner. However, the dose of extract required to reach the halfmaximal inhibitory concentration differed considerably among the various cancer cell types (Table 3). The cytotoxicity of $T$. bentzoë was also evaluated against the non-malignant human ovarian epithelial (HOE) cells and the $I C_{50}$ value obtained $(55.5 \pm 9.1 \mu \mathrm{g} / \mathrm{mL})$. HepG2 cells were more sensitive to T. bentzoë treatment (selective index value 2.4 compared to HOE cells) (Table 3). At 48 hours of exposure, the highest concentration of $T$. bentzoë extract $(100 \mu \mathrm{g} / \mathrm{mL})$ reduced HepG2 cell viability to $20 \%$ as compared to untreated control cells (Supplementary figure S1 A). Subsequently, the effect of T. bentzoë extract on the replicative ability of HepG2 cells was evaluated using the clonogenic cell survival assay. T. bentzoë treatment significantly $(\varrho<0.0001)$ reduced the number of surviving HepG2 colonies as compared to untreated control cells (Figure 1).

Table 3: Cytotoxicity $\left(I C_{50} \mu \mathrm{g} / \mathrm{ml}\right)$ of $T$. bentzoë against human cancer cell lines.

\begin{tabular}{|llllll|}
\hline Extracts & SW872 & A549 & HepG2 & Ovcar-4 & Ovcar-8 \\
T. bentzö̈ & $45.4 \pm 1.8^{* * * *}$ & $96.8 \pm 4.9^{* * * *}$ & $22.8 \pm 1.3^{* * * *}$ & $30.1 \pm 2.3$ & $38.5 \pm 4.2$ \\
Etoposide & $2.5 \pm 0.2$ & $6.8 \pm 0.7$ & $1.7 \pm 0.2$ & NA & NA \\
\hline
\end{tabular}

Data represent mean calculated $I C_{50}$ values with a standard error of the mean $(\mathrm{n}=3)$. NA= Etoposide at $1 \mu \mathrm{g} / \mathrm{ml}$. Inhibited above $80 \%$ cancer cell growth, indicating a much lower concentration is required for determination of $I C_{50}$ value. Asterisks represent significant differences between T. bentzoë and etoposide (positive control), ${ }^{* * *} \mathrm{p}$ $\leq 0.0001$.

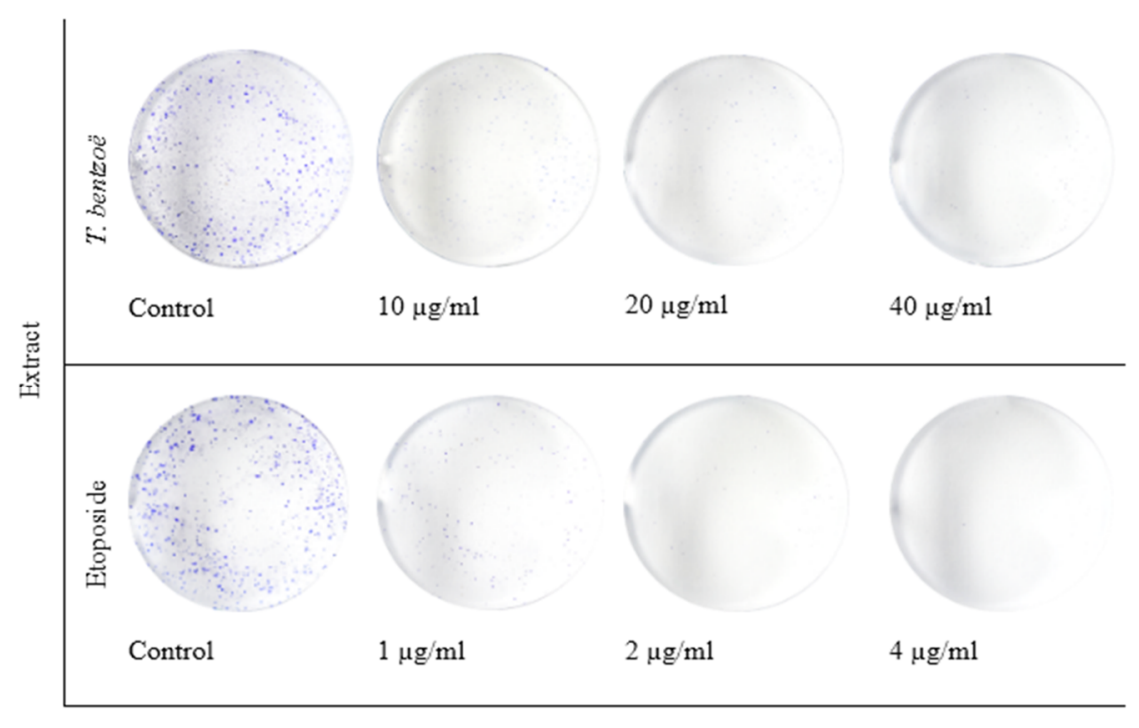

Concentration $(\mu \mathrm{g} / \mathrm{ml})$

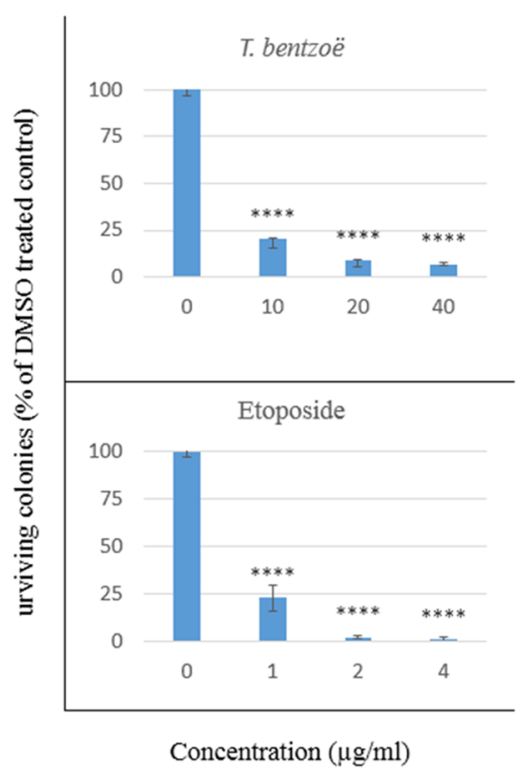

Concentration $(\mu \mathrm{g} / \mathrm{ml})$

Figure 1: HepG2 cells were treated with indicated concentrations $(\mu \mathrm{g} / \mathrm{mL})$ of test extracts for 48 hours and subsequently allowed to grow into colonies for 14 days. After 14 days, the colonies were stained with $0.1 \%$ crystal violet and the images of the wells were captured using a digital camera. The colonies were counted using Image J software. Each experiment was performed three times. Asterisks represent significant differences between extracts treatments and untreated control, ${ }^{* * * *} \mathrm{P} \leq 0.0001$.

\subsection{Genotoxic effect of T. bentzoë extract in HepG2 cells.}

DNA damage induced by T. bentzoë leaf extract was assessed in HepG2 cells by the alkaline comet assay. Treatment with $10 \mu \mathrm{g} / \mathrm{mL} \mathrm{T}$. bentzoë leaf extract for 24 hours resulted in the induction of 
significant ( $p \leq 0.0001)$ DNA damage in HepG2 cells as compared to untreated control cells. The occurrence of DNA damaged was scored in terms of tail length, tail intensity and olive tail moment of cell cultures by comet assay software (Table 4). The increased olive tail moment in response to $T$. bentzoë treatment was 4 fold higher than that of untreated control cells. Cells treated with $200 \mu \mathrm{M}$ $\mathrm{H}_{2} \mathrm{O}_{2}$ for 30 minutes, was used as a positive control.

Table 4: Tail length, tail intensity and olive tail moment of $\mathrm{H}_{2} \mathrm{O}_{2}$ and T. bentzoë treated HepG2 cells.

\begin{tabular}{|c|c|c|c|}
\hline Extracts & Tail length $(\mu \mathrm{m})$ & Tail intensity & Olive tail moment \\
\hline Negative control (Culture medium) & $32.8 \pm 0.3$ & $0.8 \pm 0.1$ & $0.2 \pm 0.0$ \\
\hline Terminalia bentzö̈ & $38.5 \pm 0.4^{* * * *}$ & $3.7 \pm 0.2^{* * * *}$ & $0.8 \pm 0.0^{* * * *}$ \\
\hline Positive control $\left(200 \mu \mathrm{M} \mathrm{H}_{2} \mathrm{O}_{2}\right)$ & $90.8 \pm 7.2^{* * * *}$ & $46.8 \pm 2.6^{* * * *}$ & $14.1 \pm 0.6^{* * * *}$ \\
\hline
\end{tabular}

Asterisks represent significant differences between extracts and untreated control, ${ }^{* * * *} \mathrm{p} \leq 0.0001$.

\subsection{T. bentzoë induced cell death.}

The proportion and distribution of HepG2 cells stained by annexin V-FITC and PI after 48 hours of exposure to T. bentzoë extract are illustrated in figure $\mathbf{2 A}$ and supplementary figure S2. The results indicated that, at a concentration equivalent to $10 \mu \mathrm{g} / \mathrm{mL}$ and $20 \mu \mathrm{g} / \mathrm{mL}$, the distribution pattern of the cell populations in the different quadrants (supplementary figure S2) is similar to that of DMSO control. However, exposure of HepG2 cells for 48 hours at $40 \mu \mathrm{g} / \mathrm{mL}$, stimulated a significant increase in annexin $\mathrm{V}(1.41$ fold, $\mathrm{p}<0.01)$ and propidium iodide $(1.52$ fold, $\mathrm{p}<0.001)$ fluorescence compared to the control, indicating apoptotic/ necrotic cell death at this test concentration. Etoposide significantly $(\mathrm{p}<0.001)$ increased the proportion of cells undergoing apoptosis/ necrosis at all three test doses, relative to DMSO control.

\subsection{Cell cycle progression and T. bentzoë.}

Flow cytometric analysis of DNA content, of HepG2 cells treated with test extracts for 48 hours, allowed the determination of the percentage of the cell population in each phase of the cell cycle. As

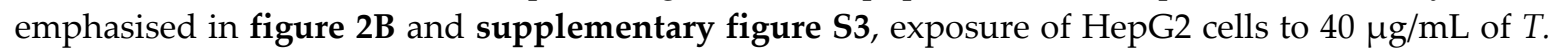
bentzoë induced G0/G1 cell cycle arrest by increasing the cell population in G0/G1 (until $73.1 \pm 1.76 \%$, $\mathrm{p}<0.01$ vs. ctrl) to the detriment of the G2/M phase (until $17.92 \pm 1.76 \%, \mathrm{p}<0.001$ vs. ctrl). In contrast, treatment with $4 \mu \mathrm{g} / \mathrm{mL}$ etoposide led to the accumulation of G2/M cell fraction (until $53.6 \pm 5.55 \%$ ) to the detriment of G0/G1 cells fraction (42.2 $\pm 6.25 \%$ ) suggesting G2/M arrest of HepG2 cell progression. 


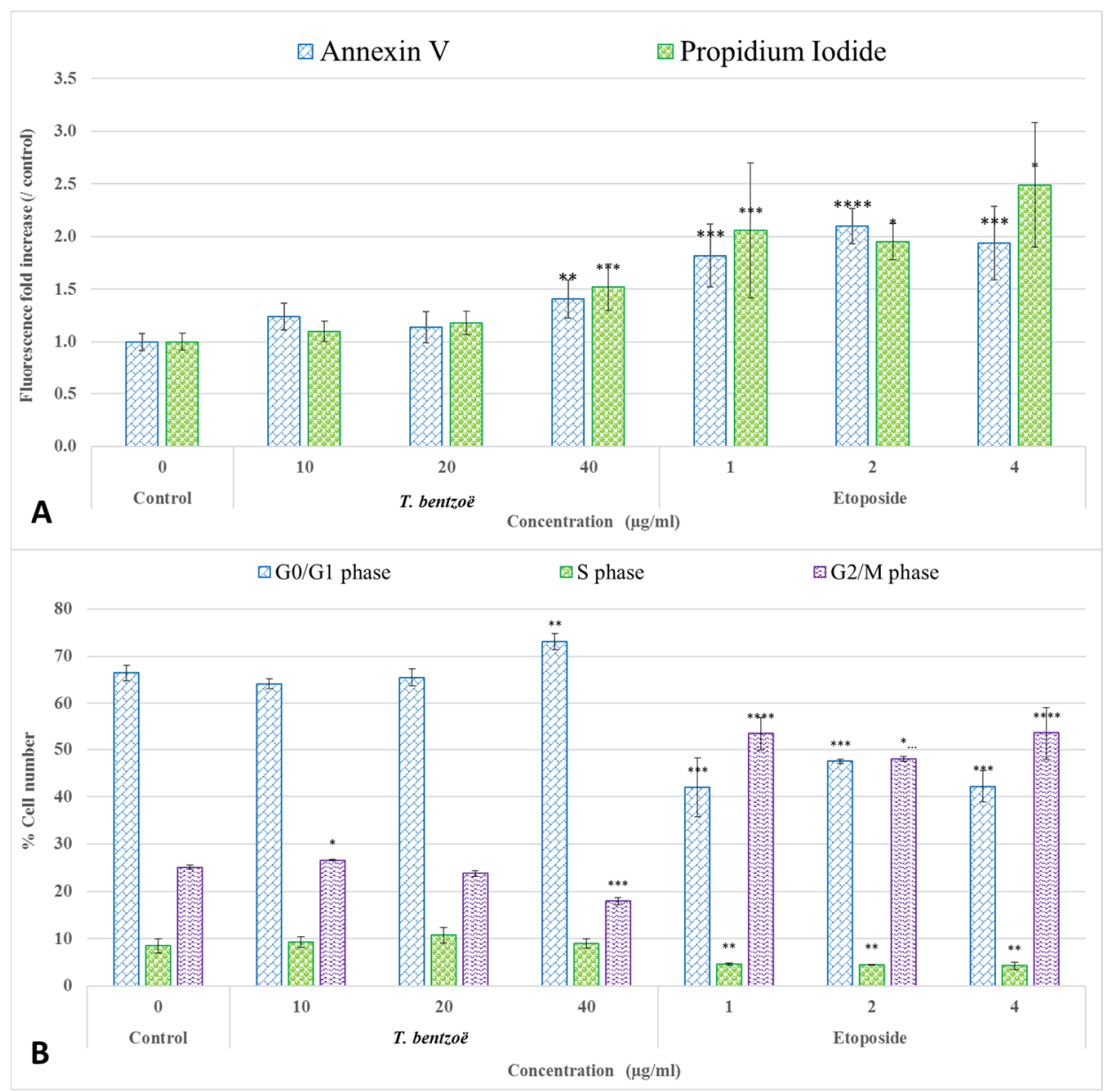

Figure 2: Effect of Terminalia bentzoë and etoposide on HepG2 cells as analysed by flow cytometry. (A) Annexin V-FITC/PI staining of HepG2 cells after 48 hours treatment and (B) cell cycle progression. Percentage of cells in different phases (GO/G1, S and G2/M phases) are expressed as mean \pm SD ( $n=3)$. Apoptosis and necrosis levels are expressed as mean \pm SD fold increase in Annexin V-FITC and PI fluorescence, respectively ( $\mathrm{n}=5$ ). Asterisks represent significant differences between test concentrations and DMSO control. ${ }^{*} \mathrm{P} \leq 0.05,{ }^{* *} \mathrm{P} \leq 0.01,{ }^{* * *} \mathrm{P} \leq 0.001$, $* * * * \mathrm{P} \leq 0.0001$.

\subsection{Bioassay guided fractionation of T. bentzoë leaf extract}

\subsubsection{Effect of T. bentzoë on HepG2 cell viability}

HepG2 cells were used as a model to fractionate and characterise the bioactive components present in T. bentzoë leaf extract. The first round of fractionation was achieved using liquid-liquid portioning with organics solvents of increasing polarities. T. bentzoë butanol fraction, being most active, was further fractionated on a Sephadex LH-20 column. A total of 11 sub-fractions was derived with cytotoxic activity being limited between fractions F4 to F10 only (Figure 3). Assessment of their chromatographic patterns revealed differences in the chemical compositions of the fractions, albeit multiple overlapping peaks highlighting the chemical complexity of the subfractions. Given the most potent cytotoxic activity of the subfraction F6 $\left(I C_{50}=15.2 \pm 1.8 \mu \mathrm{g} / \mathrm{mL}\right)$, the further fractional separation of the latter was achieved using preparative HPLC to yield 11 HPLC subfractions (F6.1 F6.11). Of these, HPLC subfraction F6.1 retained most of the cytotoxic activity, providing an $I C_{50}$ value of $15.8 \pm 0.3 \mu \mathrm{g} / \mathrm{mL}$. By contrast, HPLC fractions F.2, F.7, F.9, F.10 and F.11 failed to effectively inhibit the growth of HepG2 cell cultures; hence no $I C_{50}$ values were determined for these subfractions. A summary of the bioassay-guided fractionation employed is depicted in figure 3. 


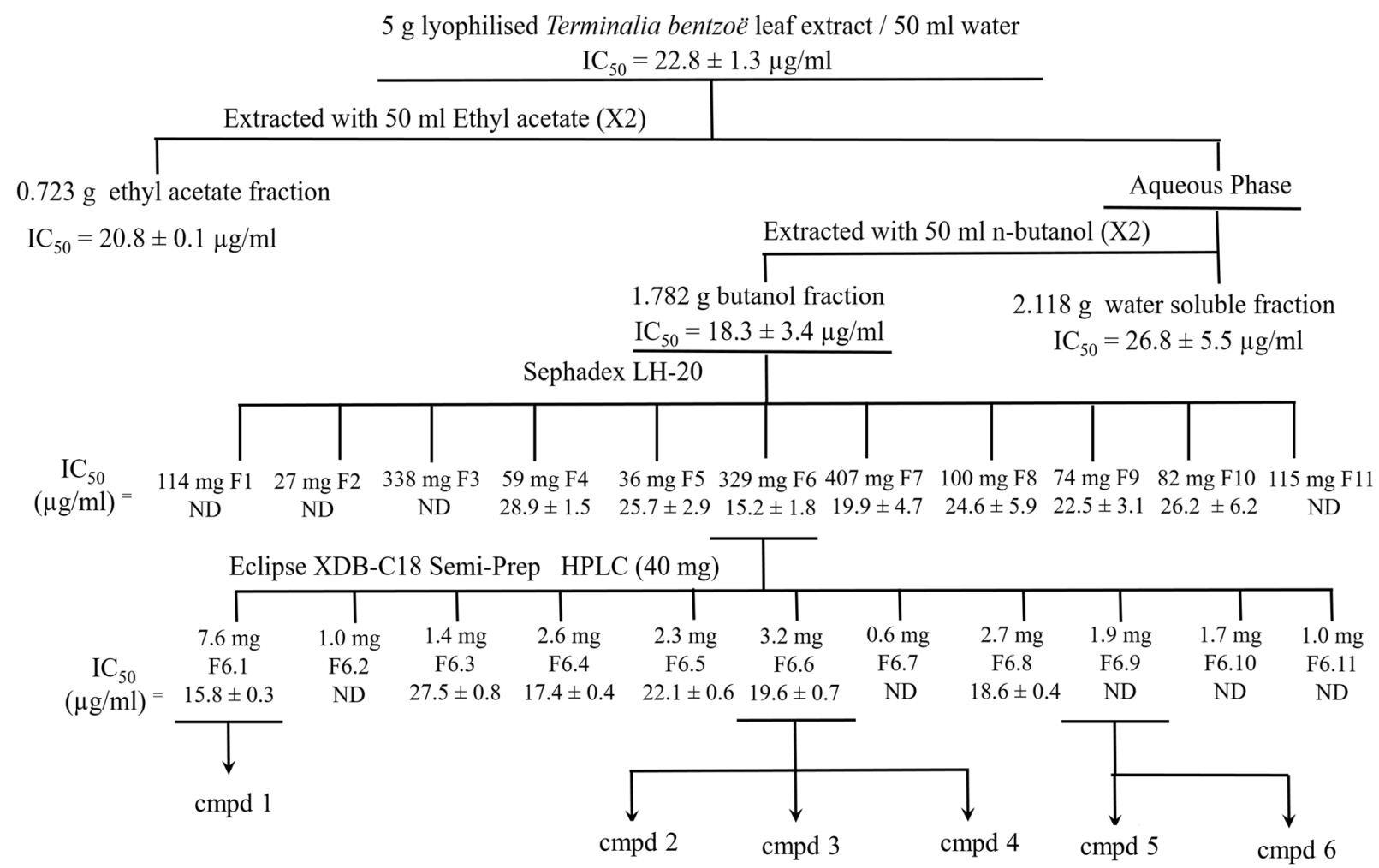

Figure 3: MTT- guided fractionation of T. bentzoë extract cytotoxicity against HepG2 cells. Cmpd: Compound. Cmpd 1= Punicalagin; compd 2= Isoterchebulin; compd 3 = Terflavin A; cmpd 4=3,4,6-trigalloyl- -Dglucopyranose, cmpd 5 =2"-O-galloyl-orientin; cmpd $6=2$ "-O-galloyl-isoorientin.

\subsubsection{Antioxidant potential of T. bentzoë fractions}

Both the ethyl acetate $\left(22 \pm 0.29 \mathrm{mmol} \mathrm{Fe}^{2+}\right)$ and butanol $\left(21.01 \pm 0.56 \mathrm{mmol} \mathrm{Fe}^{2+}\right)$ fractions were significantly $(\mathrm{p} \leq 0.05)$ higher compared to the aqueous residual fraction. Furthermore, the FRAP value of the organic fractions was greater as compared to the total extract. The butanol fraction of $T$. bentzoё was a more effective scavenger of DPPH • radical as opposed to ethyl acetate and aqueous residual fractions (Table 5). As far as the butanol subfractions were concerned, notably F6, F7, and F8 had better antioxidant activity in FRAP and superoxide radical scavenging assays (Table 5).

\subsection{Characterisation of the cytotoxic components of T. bentzoë.}

In an effort to identify the bioactive constituents in T. bentzö̈, bioassay-guided fractionation was carried out. LC-MS analysis in conjunction with NMR spectroscopy of T. bentzoë butanol fraction 6 and its semi-prep HPLC sub-fractions allowed the identification of 8 phenolic compounds including punicalagin (1), isoterchebulin (2), terflavin A (3), 3,4,6-trigalloyl- -D-glucopyranose (4), 2"-Ogalloyl-orientin (5), 2"-O-galloyl-isoorientin (6), 2"-O-galloylvitexin (7), and ellagic acid (8) (Figure 4, Table 6, Supplementary Figures S4). The bioactive HPLC subfractions F6.1 (IC50 value = $15.8 \pm 0.3$ $\mu \mathrm{g} / \mathrm{mL}$ ) revealed the presence of punicalagin (1) (Supplementary Figures S5), while a mixture of isoterchebulin (2), terflavin A (3), and 3,4,6-trigalloyl- -D-glucopyranose (4) (Supplementary Figures S6) was identified from the active subfraction F6.6 (IC50 value $=19.6 \pm 0.7 \mu \mathrm{g} / \mathrm{mL})$. A mixture of 2"-O-galloyl-orientin (5) and 2"-O-galloyl-isoorientin (6) (Supplementary Figures S7 and Table S1), with a ratio of 5:2 based on the $1 \mathrm{H}$ NMR integration of single hydrogen in each compound was identified from the non-active subfraction F6.9. 2"-O-galloylvitexin (7), and ellagic acid (8) were detected only by LC-MS from the butanol fraction 6 (Supplementary Figures S4). Additionally, two simple phenolics, gallic acid and methyl gallate were detected in both the ethyl acetate and butanol fractions and identified by GC-MS analysis (Supplementary figure S8). They were likely present in other less bioactive fractions. The levels of gallic and methyl gallate were quantified as $15.6 \pm 1.1$ and $26.2 \pm 8.1 \mu \mathrm{g} / \mathrm{mg}$ total extract) $(\mathrm{n}=3)$ by HPLC, respectively. 


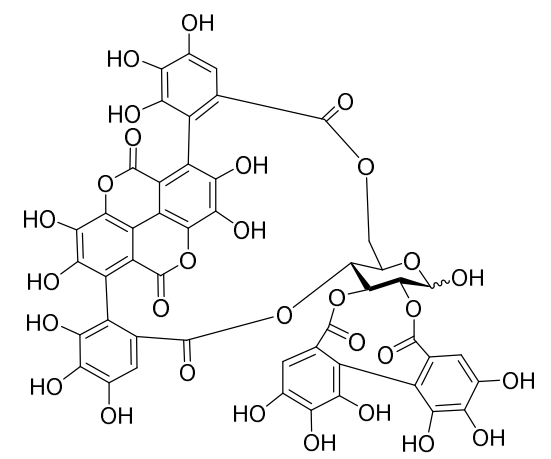

1

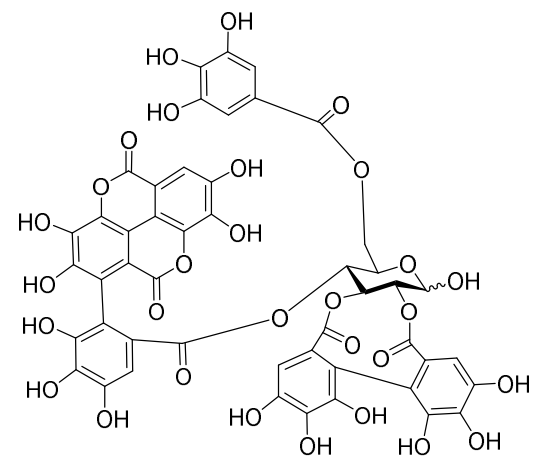

3

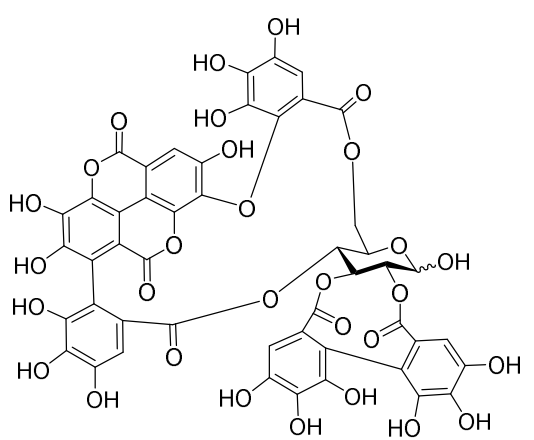

2

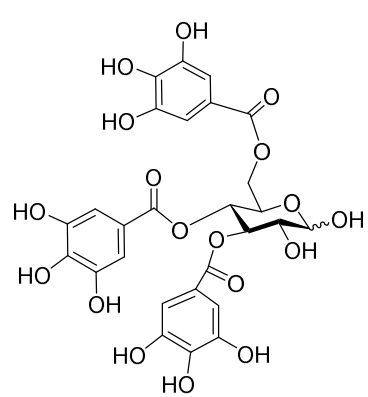

4<smiles>[R]c1cc(-c2cc(=O)c3c(O)cc(O)c(OC(O)C(O)C4OC(O)C(O)C4O)c3o2)ccc1O</smiles>

$5 \mathrm{R}=\mathrm{OH}$ $7 \mathrm{R}=\mathrm{H}$

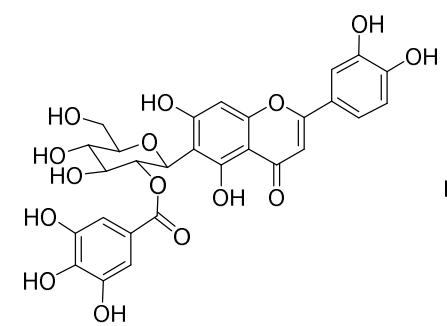

6<smiles>O=C1Oc2c(O)c(O)cc3c2c(=O)oc2c(O)c(O)cc1c23</smiles>

8

Figure 4: Chemical structure of polyphenolic compounds (1-8) identified in Terminalia bentzoë L. leaf extrac

Table 5: Antioxidant potential of T. bentzoë leaf fractions.

\begin{tabular}{|c|c|c|c|}
\hline T. bentzoë Fractions & FRAP $^{1}$ & $\mathrm{DPPH}^{2}$ & $\begin{array}{l}\text { Superoxide } \\
\text { scavenging activity }{ }^{2}\end{array}$ \\
\hline Ethyl acetate & $21.98 \pm 0.29 \mathrm{a}, \mathrm{b}$ & $1.17 \pm 0.02^{\mathrm{d}, \mathrm{e}}$ & $7.43 \pm 0.14^{b}$ \\
\hline Butanol & $21.01 \pm 0.56^{b, c}$ & $0.98 \pm 0.06^{\mathrm{e}}$ & $7.65 \pm 0.10^{\mathrm{b}}$ \\
\hline Aqueous residual & $15.29 \pm 0.16^{\mathrm{e}}$ & $1.78 \pm 0.07^{\mathrm{b}, \mathrm{c}}$ & $10.70 \pm 0.20^{a, b}$ \\
\hline 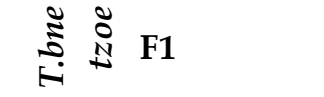 & $3.04 \pm 0.10 \mathrm{~g}$ & ND & ND \\
\hline
\end{tabular}




\begin{tabular}{|llll|}
\hline F2 & $13.62 \pm 0.16^{\mathrm{f}}$ & $2.65 \pm 0.04^{\mathrm{a}}$ & $16.90 \pm 0.35^{\mathrm{a}}$ \\
F3 & $13.80 \pm 0.14^{\mathrm{e}, \mathrm{f}}$ & $1.79 \pm 0.12^{\mathrm{b}, \mathrm{c}}$ & $10.80 \pm 0.28^{\mathrm{a}, \mathrm{b}}$ \\
F4 & $14.42 \pm 0.27^{\mathrm{e}, \mathrm{f}}$ & $2.09 \pm 0.08^{\mathrm{b}}$ & $8.96 \pm 0.12^{\mathrm{b}}$ \\
F5 & $18.46 \pm 0.15^{\mathrm{d}}$ & $1.71 \pm 0.07^{\mathrm{c}}$ & $8.71 \pm 0.10^{\mathrm{b}}$ \\
F6 & $23.01 \pm 0.68^{\mathrm{a}}$ & $1.19 \pm 0.09^{\mathrm{d}, \mathrm{e}}$ & $7.03 \pm 0.20^{\mathrm{b}}$ \\
F7 & $20.94 \pm 0.49^{\mathrm{b}, \mathrm{c}}$ & $1.01 \pm 0.07^{\mathrm{d}, \mathrm{e}}$ & $7.15 \pm 0.18^{\mathrm{b}}$ \\
F8 & $19.86 \pm 0.29^{\mathrm{c}, \mathrm{d}}$ & $1.12 \pm 0.06^{\mathrm{d}, \mathrm{e}}$ & $8.76 \pm 0.08^{\mathrm{b}}$ \\
F9 & $18.82 \pm 0.31^{\mathrm{d}}$ & $0.99 \pm 0.06^{\mathrm{e}}$ & $9.33 \pm 0.24^{\mathrm{b}}$ \\
F10 & $18.47 \pm 0.28^{\mathrm{d}}$ & $1.34 \pm 0.04^{\mathrm{d}}$ & $9.05 \pm 0.23^{\mathrm{b}}$ \\
F11 & $0.09 \pm 0.02^{\mathrm{h}}$ & $\mathrm{ND}$ & $\mathrm{ND}$ \\
\hline
\end{tabular}

${ }^{1}$ Values are expressed in units of $\mathrm{mmol} \mathrm{Fe}^{2+} / \mathrm{gFDW} ;{ }^{2}$ Values are expressed in units of $\mu \mathrm{g} / \mathrm{mL}$; Data represent mean with a standard error of the mean $(n=3)$. Different letters between rows in each column represent significant differences between extracts $(\mathrm{p}<0.05)$. ND $=\mathrm{IC}_{50}$ value not reached at maximun test dose.

Table 6: Identification of phenolic compound in T. bentzoë butanol fraction F6 using high-resolution mass sectrometry, NMR spectroscopy, and comparison with literature and available data

\begin{tabular}{|c|c|c|c|c|c|c|}
\hline $\begin{array}{l}\text { Compound } \\
\text { number }\end{array}$ & $\mathrm{RT} / \mathrm{min}$ & $\begin{array}{l}\text { Negative } \\
{[\mathrm{M}-\mathrm{H}]^{-}}\end{array}$ & ESI-MS & $\begin{array}{l}\text { Molecular } \\
\text { formula }\end{array}$ & Compound & References \\
\hline 1 & 0.76 & 1083.0555 & & $\mathrm{C}_{48} \mathrm{H}_{28} \mathrm{O}_{30}$ & Punicalagin & {$[58,59,65,66]$} \\
\hline 2 & 4.08 & 1083.0555 & & $\mathrm{C}_{48} \mathrm{H}_{28} \mathrm{O}_{30}$ & Isoterchebulin & {$[58]$} \\
\hline 3 & 4.58 & 1085.0710 & & $\mathrm{C}_{48} \mathrm{H}_{30} \mathrm{O}_{30}$ & Terflavin A & {$[60]$} \\
\hline 4 & 4.97 & 635.0867 & & $\mathrm{C}_{27} \mathrm{H}_{24} \mathrm{O}_{18}$ & $\begin{array}{l}\text { 3,4,6-trigalloyl- -D- } \\
\text { glucopyranose }\end{array}$ & {$[67]$} \\
\hline 5 & 6.25 & 599.1017 & & $\mathrm{C}_{28} \mathrm{H}_{24} \mathrm{O}_{15}$ & 2"-O-galloyl-orientin & {$[65]$} \\
\hline 6 & 6.25 & 599.1017 & & $\mathrm{C}_{28} \mathrm{H}_{24} \mathrm{O}_{15}$ & $\begin{array}{l}\text { 2"-O-galloyl- } \\
\text { isoorientin }\end{array}$ & {$[65]$} \\
\hline 7 & 6.53 & 583.1074 & & $\mathrm{C}_{28} \mathrm{H}_{24} \mathrm{O}_{14}$ & 2"-O-Galloylvitexin & {$[59,65]$} \\
\hline 8 & 6.72 & 300.9987 & & $\mathrm{C}_{14} \mathrm{H}_{6} \mathrm{O}_{8}$ & Ellagic acid & {$[58]$} \\
\hline
\end{tabular}

4 Discussion

Medicinal plants are known to be the epicentre of numerous well established ethnomedicinal systems across the globe [4]. However, more than $84 \%$ of these medicinal plants have been poorly studied in regards to their phytochemical compositions, clinical efficacy as well as their safety and toxicological profiles [4]. Moreover, forest cover is being uprooted across the world, at an unprecedented rate, threatening the survival of at least 15000 medicinal plant species [25]. Plant secondary metabolites have contributed enormously to the modern-day pharmaceutical industry by providing the chemical backbone for almost $25 \%$ of the 1562 clinical agents as well as $60 \%$ of the 246 oncologic drugs 
approved by the US Federal Drugs Administration between 1981 and 2014 [1,2,26]. As such it is of utmost importance to evaluate the unexplored terrestrial flora for their therapeutic potential, as the dwindling medicinal plant's species continues to stand as a rich repository to probe for novel chemotypes in the drug developmental process.

The current findings highlighted the richness of the different subclasses of polyphenolics, notably phenolics, flavonoids and proanthocyanidins, the distribution of which differed significantly $(\mathrm{p}<$ 0.05) among the investigated accessions (Table 2). The biosynthesis of flavonoids, in particular flavonols, are known to be upregulated in response to ultra-violet radiation [27]. The accumulation of flavonoids in the endemic plant leaves collected from Mauritius may be attributed to the high sunlight conditions and UV radiation which are characteristic to tropical islands like the Mascarene [28]. Given the ubiquitous involvement of oxidative damage in carcinogenesis, antioxidant-rich secondary metabolites, notably, polyphenolics have attracted much interest in the search of novel and alternative treatment modalities for cancer $[29,30]$. In this vein, the in vitro antioxidant activities correlated strongly with the growth inhibitory activity against cancer cell lines [31,32]. The antioxidant mechanism of action of polyphenols, especially flavonoids are multifaceted, thus a panel of in vitro assay models allowed to gauge the antioxidant potential of the evaluated extracts [33]. $T$. bentzoë having the highest abundance of TPC as well as TFC also exhibited the most potent antioxidant activity in all six in vitro assays and was further evaluated for its cytotoxicity against cancer cell lines.

The cytotoxicity of different Terminalia species against multiple cancerous cell lines is documented. Investigation of the cytotoxic activity of methanolic leaf extracts of T. arjuna against human chronic myelogenous leukaemia cells led to the isolation of the bioactive ursolic acid (triterpenoid) [34]. Leaf extracts of $T$. chebula suppressed the growth of human breast and lung cancer cell lines [35]. Along a similar line, the leaf extract from $T$. catappa significantly $(p<0.05)$ suppressed the proliferation of human colorectal (SW480) cell line in a dose-dependent manner by downregulating the level of Bcell lymphoma 2 (BCL-2) gene expression while upregulating the level of Caspase 9 and Caspase 3, indicative of the mitochondrial pathway of apoptosis in SW480 cells [36].

The foremost aim of oncologic agents is to precisely target cancerous cells with minimal effect on non-malignant cells. T. bentzoë crude extract had a selective index value of approximately 2.5, indicating that the extract had some degree of selectivity towards HepG2 cells as opposed to nonmalignant human ovarian epithelial cells. Nevertheless, it is crucial to also assess the cytotoxicity of the extract against a panel of normal cells of different tissue origins, to provide greater insight regarding its toxicity window and safety profile.

In line with the United States National Cancer Institute cytotoxicity guidelines [37,38], T. bentzoë crude extract with an $I C_{50}$ value of $22.8 \pm 1.3 \mu \mathrm{g} / \mathrm{mL}$ can be considered as a potent candidate for further investigation with regards to its anticancer potential. It is known that, following exposure to toxicants, a subpopulation of cells enter a dormant state. These dormant viable cells further retained their ability to replicate into stem-like progeny cells which might lead to the development of drugresistance and cancer relapse $[39,40]$. Thus, while investigating the potential anticancer effect of extracts, it is warranted to also evaluate their long-term effect on the replicative ability of the cancer cell line. The colony formation assay is a simple and useful in vitro model, considered as the gold standard to predict the long-term sensitivity of cancer cell response to therapeutics treatment $[39,41]$. In this vein, the current study evidenced the ability of $T$. bentzoë to impede the replicative potential of HepG2 cells (Figure 1). Numerous anticancer agents, including polyphenols, are known to abrogate the limitless replicative ability of different cancer cell variants [42,43]. Catechin, catechin-3O-gallate, 7-O-galloyl catechin, and methyl gallate purified from Acasis hydaspica is reported to suppress the long-term clonal proliferation of prostate cancer (PC-3) cells [44].

This study also attempted to delineate the mode of T. bentzoë induced HepG2 cell death. Flow cytometric analysis of annexin V-FITC and PI dual stained HepG2 cells treated with $40 \mu \mathrm{g} / \mathrm{mL}$, revealed a significant $(\mathrm{p}<0.05)$ increased in both Annexin V-FITC and PI fluorescence level, 
compared to the untreated control, thus indicating the putative activation of both apoptotic and necrotic pathways in HepG2 cells. Cells grown as monoculture are known to initiate apoptosis which is terminated by necrosis like events, also termed as secondary necrosis, due to the absence of phagocytic scavenger cells $[45,46]$. Numerous studies evidenced this type of cancer cell death following treatment with cytotoxic agents. Ellagic acid was reported to induce both apoptotic and necrotic cell death mechanism in human pancreatic cancer cell cultures [47]. A similar effect of Lepidium sativum and Vitis vinifera extract were highlighted in human breast and skin cancer cells, respectively [48,49].

Plant extracts and/or thereby derived phytochemicals are known to provoke cancer cell death by causing oxidative damage to genetic material mediated cell cycle arrest and subsequent cell death [50,51]. With this in mind, the DNA damage to HepG2 cellular DNA following T. bentzoë crude extracts treatment was investigated using the alkaline comet assay and scored in terms of tail length, tail intensity, and olive tail moment. The comet assay is a well-established and highly sensitive method for the detection of DNA damage and fragmentation pattern [52]. T. bentzoë induced 4 folds significantly $(\mathrm{p}<0.001)$ higher DNA damaged to HepG2 cells compared to the untreated control, as reflected by the olive tail moments (Table 4). Consistent with the DNA damaging ability, T. bentzoë halted the cell cycle progression significantly ( $p<0.01$, versus control) in the G0/G1 phase (Figure 2). A similar observation was reported in lung cancer cells, where casuarinin, a tannin purified from $T$. arjuna L. bark, provoked apoptotic mechanism via DNA fragmentation and G0/G1 phase cell cycle arrest [53].

It is noteworthy that, the cytotoxicity of the extract may arise from the complex interplay of the cocktails of secondary metabolites present, which may act either synergistically or antagonistically to produce the overall results. Also, crude extracts often comprised a pool of inactive phytoconstituents that dilute the efficacy of the active components $[54,55]$. It is therefore of paramount importance to purify and identify the principal bioactive components to conduct further mechanistic studies to establish their molecular mode of action [54,56]. Moreover, isolating the lead compounds also allows for the potential structural modification in an attempt to enhance their selectivity and potency [57]. As such, the MTT-guided fractionation revealed that only six out of the eleven preparative HPLC subfractions retained the potent cytotoxicity of the crude extract (Figure 3). The HPLC subfraction F6.1 was 1.4 folds more potent as compared to the crude extract.

LC-MS analysis in conjunction with NMR spectroscopy allowed the identification of 8 phenolic compounds from the most bioactive subfraction F6. Punicalagin, isoterchebulin and ellagic acid have been previously reported from the bark extract of the same species collected in Réunion Island [58]. Although, the other identified compounds are being reported for the first time, to the best of our current knowledge, in T. bentzoë leaf, some were reported in the leaf extracts of other Terminalia species. For instance, 2"-O-galloylvitexin and gallic acid were identified from T. brachystemma Welw. ex Hiern and T. mollis M. Laws leaves, respectively [59]. Likewise, terflavin A was found in T. catappa L. leaf [60].

Punicalagin and ellagic acid were reported to induce S Phase arrest and G0/G1 phase arrest in HepG2 cells, respectively [61]. Ellagic acid administration in prostate cancer patients was associated with decreased prostate-specific antigen as well as reduced chemotherapy-induced myelotoxicity [62]. It may be strongly proposed that the overall cytotoxicity of $T$. bentzoë leaf extract may be a synergistic effect of the identified compounds. Gallic acid was reported to induce $S$ phase arrest in HepG2 cells [63] and be cytotoxic to ovarian cancer cells [64]. Furthermore, gallic acid was also shown to impair centrosomal clustering in Hela cells, thus causing a mitotic catastrophe and ultimate cell G2/M phase cell cycle arrest.

\section{Conclusion}

The findings evidenced the selective long-term cytotoxicity of the antioxidant-rich T. bentzoë leaf extract against HepG2 cells. This plant which is also used traditionally in the mitigation of asthma, 
haemorrhages, diarrhoea, and sexually transmissible diseases, amongst others, has also shown some in-vitro anticancer activities against HepG2 cells. The cytotoxic nature of T. bentzoë leaf extract against cancerous cells indicated that $T$. bentzoë leaf has the potential to be repurposed in the mitigation of cancer as part of traditional medicine. The results so far generated, supports the hypothesis that $T$. bentzoë extract induced apoptosis/necrosis cell death in HepG2 cells via the degradation of cellular genetic material and subsequent arrest of the cell cycle progression in G0/G1 phase. Overall, the MTTguided fractionation of the crude extract allowed the characterisation of 10 phenolic compounds including gallic acid, methyl gallate, punicalagin, and ellagic acid that are known to have established in vitro and in vivo anticancer activities. However, the contribution of the other non-identified phytoconstituents cannot be excluded and thus further evaluation of purified identified components is warranted alongside the crude extract. The metabolite profiling of the leaf extract may be envisaged in future studies. This will allow to precisely ascribe the bioactive molecules present in T. bentzoë leaf. Taking into consideration the guidelines of the US national cancer institute as well as the selectivity index observed in this study, T. bentzoë leaf extract revealed as a promising candidate that can be exploited in the search for novel anticancer agents, Further mechanistic investigation, directed towards delineating the molecular mechanisms via which the purified bioactive entities target of the aberrant signalling pathways involved in carcinogenesis, is needed to fuel in-vivo studies.

\section{Supplementary Materials}

Figure S1: Cell viability profile of HepG2 cells treated with T. bentzoë extract and fractions.

Figure S2: Representatives annexin V-FITC/PI flow cytometric profile of HepG2 cells, 48 hours post extract/control treatment.

Figure S3: Representatives cell cycle histogram of HepG2 cells, 48 hours post extract/control treatment.

Figure S4: UPLC ESI MS of the butanol fraction 6 at the positive (A) and negative (B) mode.

Figure S5: ${ }^{1} \mathrm{H}$ NMR spectrum (A) and HSQC spectrum (B) for punicalagin (1) present in a mixture in an HPLC fraction at RT 2-3 min in methanol-d4.

Figure S6: ${ }^{1} \mathrm{H}$ NMR spectra for a mixture of isoterchebulin (2), terflavin A (3), and 3,4,6-trigalloyl-beta-Dglucopyranose (4) in a HPLC fraction at RT18-20 $\mathrm{min}$ in acetone- $\mathrm{d}_{6}(\mathrm{~A})$ and methanol- $\mathrm{d}_{4}(\mathrm{~B})$.

Figure S7: ${ }^{1} \mathrm{H}$ NMR spectra for a mixture of 2"-O-galloyl-orientin (3) and 2"-O-galloyl-isoorientin (6) with a ratio of 5:2 based on the integration of single hydrogen in each compound.

Figure S8: GC -MS chromatogram of TMSi derivatives of ethyl acetate (A) and butanol (B) fraction of T. bentzoë.

Table $\mathrm{S}^{1}{ }^{1} \mathrm{H}$ NMR spectral data (500 MHz, $\mathrm{CD}_{3} \mathrm{OD}$ ) of the O-galloyl-C-glycosylflavones 7 and 8 (5:2) [" in ppm, multiplicities and $\mathrm{J}$ values $(\mathrm{Hz})$ are given in parentheses].

Author Contributions: Conceptualization, N.R and V.N; methodology, N.R., P.R, E.P., J.M., and T.D.; software, N.R., P.R, E.P., J.M., and T.D.; validation, N.R., P.R, E.P., J.M., and T.D.; formal analysis, N.R., P.R, E.P., J.M., and T.D.; investigation, N.R., P.R, E.P., J.M., and T.D.; resources, E.B., T.B., W.L., and V.N.; data curation, N.R., P.R, E.P., J.M., and T.D.; writing-original draft preparation, N.R.; writing-review and editing, P.R, T.D., T.B., W.L., E.B., and V.N.; visualization, N.R., E.P., J.M., and T.D ; supervision, T.B., W.L., and V.N.; project administration, T.B., V.N.; funding acquisition, T.B., W.L., and V.N. All authors have read and agreed to the published version of the manuscript.

\section{Acknowledgements}

We thank the director and staff of Alteo Group, Médine Sugar Estate and Mauritius National Park Conservation Services under the Ministry of Agro-Industry \& Food Security, Mauritius, for permission to collect endemic plant samples and the Mauritius Herbarium for plant identification. This study was supported by the Royal Society and Royal Society of Chemistry international exchange award, Mauritius Research Council under the National Research and Innovation Chair Program studentship. 


\section{Conflicts of interest}

The authors declare no conflict of interest.

\section{References}

1. Newman, D.J.; Cragg, G.M. Natural products as sources of new drugs from 1981 to 2014. J. Nat. Prod. 2016, 79, 629-661, doi:10.1021/acs.jnatprod.5b01055.

2. Thomford, N.; Senthebane, D.; Rowe, A.; Munro, D.; Seele, P.; Maroyi, A.; Dzobo, K. Natural products for drug discovery in the 21st century: Innovations for novel drug discovery. Int. J. Mol. Sci. 2018, 19, 1578-1607, doi:10.3390/ijms19061578.

3. Graham, J.G.; Quinn, M.L.; Fabricant, D.S.; Farnsworth, N.R. Plants used against cancer - an extension of the work of Jonathan Hartwell. J. Ethnopharmacol. 2000, 73, 347-377, doi:10.1016/S0378-8741(00)00341-X.

4. Willis, K.J. State of the World's Plants 2017. Report. Royal Botanic Gardens, Kew.; 2017;

5. Ang, L.; Song, E.; Lee, H.W.; Lee, M.S. Herbal medicine for the treatment of coronavirus disease 2019 (COVID-19): A systematic review and meta-analysis of randomized controlled trials. J. Clin. Med. 2020, 9, 1583, doi:10.3390/jcm9051583.

6. Ang, L.; Lee, H.W.; Kim, A.; Lee, M.S. Herbal medicine for the management of COVID-19 during the medical observation period: A review of guidelines. Integr. Med. Res. 2020, 9 , 100465, doi:10.1016/j.imr.2020.100465.

7. Panyod, S.; Ho, C.-T.; Sheen, L.-Y. Dietary therapy and herbal medicine for COVID-19 prevention: A review and perspective. J. Tradit. Complement. Med. 2020, 10, 420-427, doi:10.1016/j.jtcme.2020.05.004.

8. Myers, N.; Mittermeier, R.A.; Mittermeier, C.G.; da Fonseca, G.A.B.; Kent, J. Biodiversity hotspots for conservation priorities. Nature 2000, 403, 853-858, doi:10.1038/35002501.

9. Kinghorn, A.D.; Farnsworth, N.R.; Soejarto, D.D.; Cordell, G.A.; Pezzuto, J.M.; Udeani, G.O.; Wani, M.C.; Wall, M.E.; Navarro, H.A.; Kramer, R.A.; et al. Novel strategies for the discovery of plant-derived anticancer agents. Pure Appl. Chem. 1999, 71, 1611-1618.

10. Kinghorn, A.D.; De Blanco, E.J.C.; Lucas, D.M.; Rakotondraibe, H.L.; Orjala, J.; Soejarto, D.D.; Oberlies, N.H.; Pearce, C.J.; Wani, M.C.; Stockwell, B.R.; et al. Discovery of anticancer agents of diverse natural origin. Anticancer Res. 2016, 36, 5623-5638, doi:10.21873/anticanres.11146.

11. Rasoanaivo, P. Rain forests of Madagascar : Sources of industrial and medicinal plants. Ambio 1990, 19, 421-424.

12. Das, A.; Sarkar, S.; Bhattacharyya, S.; Gantait, S. Biotechnological advancements in Catharanthus roseus (L.) G. Don. Appl. Microbiol. Biotechnol. 2020, 104, 4811-4835, doi:10.1007/s00253-020-10592-1.

13. Alam, P.; Sharaf-Eldin, M. Limited production of plant derived anticancer drugs vinblastine and vincristine. Planta Med. 2016, 82, doi:10.1055/s-0036-1578706.

14. Garot, E.; Joët, T.; Combes, M.-C.; Lashermes, P. Genetic diversity and population divergences of an indigenous tree (Coffea mauritiana) in Reunion Island: role of climatic and geographical factors. Heredity (Edinb). 2019, 122, 833-847, doi:10.1038/s41437-018-0168-9.

15. Baider, C.; Florens, F.B.V.; Baret, S.; Beaver, K.; Strasberg, D.; Kueffer, C. Status of plant conservation in oceanic islands of the Western Indian Ocean. Proc. 4th Glob. Bot. Gard. Congr. 2010, 1-7.

16. Rummun, N.; Neergheen-Bhujun, V.S.; Pynee, K.B.; Baider, C.; Bahorun, T. The role of endemic plants in Mauritian traditional medicine - Potential therapeutic benefits or placebo effect? J. Ethnopharmacol. 2018, 213, 111-117, doi:10.1016/j.jep.2017.10.006.

17. Humphreys, A.M.; Govaerts, R.; Ficinski, S.Z.; Nic Lughadha, E.; Vorontsova, M.S. Global dataset shows geography and life form predict modern plant extinction and rediscovery. Nat. Ecol. Evol. 2019, 3, 1043-1047, doi:10.1038/s41559-019-0906-2.

18. Rummun, N.; Somanah, J.; Ramsaha, S.; Bahorun, T.; Neergheen-Bhujun, V.S. Bioactivity of nonedible parts of Punica granatum L.: A Potential source of functional ingredients. Int. J. 
Food Sci. 2013, 2013, 1-12, doi:10.1155/2013/602312.

19. Rummun, N.; Hughes, R.E.; Beesoo, R.; Li, W.W.; Aldulaimi, O.; Macleod, K.G.; Bahorun, T.; Carragher, N.O.; Kagansky, A.; Neergheen-Bhujun, V.S. Mauritian endemic medicinal plant extracts induce G2/M phase cell cycle arrest and growth inhibition of oesophageal squamous cell carcinoma in vitro. Acta Naturae 2019, 11, 81-90, doi:10.32607/20758251-2019-11-1-81-90.

20. Ramful, D.; Tarnus, E.; Rondeau, P.; Robert Da Silva, C.; Bahorun, T.; Bourdon, E. Citrus fruit extracts reduce advanced glycation end products (AGEs)- and $\mathrm{H}_{2} \mathrm{O}_{2}$-induced oxidative stress in human adipocytes. J. Agric. Food Chem. 2010, 58, 11119-11129, doi:10.1021/jf102762s.

21. Collins, A.R. The comet assay for dna damage and repair: Principles, applications, and limitations. Mol. Biotechnol. 2004, 26, 249-261, doi:10.1385/MB:26:3:249.

22. Miyaji, C.; Jordão, B.; Ribeiro, L.; Eira, A.; Cólus, I. Genotoxicity and antigenotoxicity assessment of shiitake (Lentinula edodes (Berkeley) Pegler) using the Comet assay. Genet. Mol. Biol. 2004, 27, 108-114, doi:10.1590/S1415-47572004000100018.

23. Catan, A.; Turpin, C.; Diotel, N.; Patche, J.; Guerin-Dubourg, A.; Debussche, X.; Bourdon, E.; Ah-You, N.; Le Moullec, N.; Besnard, M.; et al. Aging and glycation promote erythrocyte phagocytosis by human endothelial cells: Potential impact in atherothrombosis under diabetic conditions. Atherosclerosis 2019, 291, 87-98, doi:10.1016/j.atherosclerosis.2019.10.015.

24. Bai, J.; Cederbaum, A.I. Cycloheximide protects HepG2 cells from serum withdrawalinduced apoptosis by decreasing p53 and phosphorylated p53 Levels. J. Pharmacol. Exp. Ther. 2006, 319, 1435-1443, doi:10.1124/jpet.106.110007.

25. Brower, V. Back to nature: Extinction of medicinal plants threatens drug discovery. JNCI J. Natl. Cancer Inst. 2008, 100, 838-839, doi:10.1093/jnci/djn199.

26. Anand, U.; Jacobo-Herrera, N.; Altemimi, A.; Lakhssassi, N. A comprehensive review on medicinal plants as antimicrobial therapeutics: Potential avenues of biocompatible drug discovery. Metabolites 2019, 9, 1-13, doi:10.3390/metabo9110258.

27. Ferreyra, F.M.L.; Rius, S.P.; Casati, P. Flavonoids: biosynthesis, biological functions, and biotechnological applications. Front. Plant Sci. 2012, 3, 1-15, doi:10.3389/fpls.2012.00222.

28. Bahorun, T.; Ramful-Baboolall, D.; Neergheen-Bhujun, V.; Aruoma, O.I.; Kumar, A.; Verma, S.; Tarnus, E.; Da Silva, C.R.; Rondeau, P.; Bourdon, E. Phytophenolic nutrients in citrus: Biochemical and molecular evidence. In Advances in Citrus Nutrition; Srivastava, A.K., Ed.; Springer Netherlands: Dordrecht, 2012; Vol. 9789400741, pp. 25-40 ISBN 978-94-007-4170-6.

29. Perillo, B.; Di Donato, M.; Pezone, A.; Di Zazzo, E.; Giovannelli, P.; Galasso, G.; Castoria, G.; Migliaccio, A. ROS in cancer therapy: the bright side of the moon. Exp. Mol. Med. 2020, 52, 192-203, doi:10.1038/s12276-020-0384-2.

30. Ashraf, M.A. Phytochemicals as potential anticancer drugs: Time to ponder nature's bounty. Biomed Res. Int. 2020, 2020, 1-7, doi:10.1155/2020/8602879.

31. Li, W.-Y.; Chan, S.-W.; Guo, D.-J.; Yu, P.H.-F. Correlation between antioxidative power and anticancer activity in herbs from traditional Chinese medicine formulae with anticancer therapeutic effect. Pharm. Biol. 2007, 45, 541-546, doi:10.1080/13880200701498879.

32. Sammar, M.; Abu-Farich, B.; Rayan, I.; Falah, M.; Rayan, A. Correlation between cytotoxicity in cancer cells and free radical-scavenging activity: In vitro evaluation of 57 medicinal and edible plant extracts. Oncol. Lett. 2019, 18, 6563-6571, doi:10.3892/ol.2019.11054.

33. Procházková, D.; Boušová, I.; Wilhelmová, N. Antioxidant and prooxidant properties of flavonoids. Fitoterapia 2011, 82, 513-523, doi:10.1016/j.fitote.2011.01.018.

34. Moulisha, B.; Ashok Kumar, G.; Pallab Kanti, H. Anti-leishmanial and anti-cancer activities of a pentacyclic triterpenoid isolated from the leaves of Terminalia arjuna Combretaceae. Trop. J. Pharm. Res. 2010, 9, 135-140, doi:10.4314/tjpr.v9i2.53700.

35. Shankara, R.B.; Ramachandra, Y.; Rajan, S.S.; Sujan Ganapathy, P.; Yarla, N.; Richard, S.; Dhananjaya, B. Evaluating the anticancer potential of ethanolic gall extract of Terminalia chebula (Gaertn.) Retz. (combretaceae). Pharmacognosy Res. 2016, 8, 209, doi:10.4103/09748490.182919.

36. Shanehbandi, D.; Zarredar, H.; Asadi, M.; Zafari, V.; Esmaeili, S.; Seyedrezazadeh, E.; 
Soleimani, Z.; Sabagh Jadid, H.; Eyvazi, S.; Feyziniya, S.; et al. Anticancer impacts of Terminalia catappa extract on SW480 colorectal neoplasm cell line. J. Gastrointest. Cancer 2019, doi:10.1007/s12029-019-00349-z.

37. Ramos-Silva, A.; Tavares-Carreón, F.; Figueroa, M.; De la Torre-Zavala, S.; GastelumArellanez, A.; Rodríguez-García, A.; Galán-Wong, L.J.; Avilés-Arnaut, H. Anticancer potential of Thevetia peruviana fruit methanolic extract. BMC Complement. Altern. Med. 2017, 17, 241, doi:10.1186/s12906-017-1727-y.

38. Vijayarathna, S.; Sasidharan, S. Cytotoxicity of methanol extracts of Elaeis guineensis on MCF7 and Vero cell lines. Asian Pac. J. Trop. Biomed. 2012, 2, 826-829, doi:10.1016/S22211691(12)60237-8.

39. Mirzayans, R.; Andrais, B.; Murray, D. Viability assessment following anticancer treatment requires single-cell visualization. Cancers (Basel). 2018, 10, 255, doi:10.3390/cancers10080255.

40. Jahanban-Esfahlan, R.; Seidi, K.; Manjili, M.H.; Jahanban-Esfahlan, A.; Javaheri, T.; Zare, P. Tumor cell dormancy: Threat or opportunity in the fight against cancer. Cancers (Basel). 2019, 11, 1-23, doi:10.3390/cancers11081207.

41. Mirzayans, R.; Murray, D. Intratumor heterogeneity and therapy resistance: Contributions of dormancy, apoptosis reversal (anastasis) and cell fusion to disease recurrence. Int. J. Mol. Sci. 2020, 21, 1308, doi:10.3390/ijms21041308.

42. Myint, P.P.; Dao, T.T.P.; Kim, Y.S. Anticancer activity of Smallanthus sonchifolius methanol extract against human hepatocellular carcinoma cells. Molecules 2019, 24, 3054, doi:10.3390/molecules24173054.

43. Khorsandi, K.; Kianmehr, Z.; Hosseinmardi, Z.; Hosseinzadeh, R. Anti-cancer effect of gallic acid in presence of low level laser irradiation: ROS production and induction of apoptosis and ferroptosis. Cancer Cell Int. 2020, 20, 18, doi:10.1186/s12935-020-1100-y.

44. Afsar, T.; Trembley, J.H.; Salomon, C.E.; Razak, S.; Khan, M.R.; Ahmed, K. Growth inhibition and apoptosis in cancer cells induced by polyphenolic compounds of Acacia hydaspica: Involvement of multiple signal transduction pathways. Sci. Rep. 2016, 6, doi:10.1038/srep23077.

45. Silva, M.T. Secondary necrosis: The natural outcome of the complete apoptotic program. FEBS Lett. 2010, 584, 4491-4499, doi:10.1016/j.febslet.2010.10.046.

46. Lee, S.Y.; Ju, M.K.; Jeon, H.M.; Jeong, E.K.; Lee, Y.J.; Kim, C.H.; Park, H.G.; Han, S.I.; Kang, H.S. Regulation of tumor progression by programmed necrosis. Oxid. Med. Cell. Longev. 2018, 2018, 1-28, doi:10.1155/2018/3537471.

47. Edderkaoui, M.; Odinokova, I.; Ohno, I.; Gukovsky, I.; Go, V.L.W.; Pandol, S.J.; Gukovskaya, A.S. Ellagic acid induces apoptosis through inhibition of nuclear factor $\mathrm{kB}$ in pancreatic cancer cells. World J. Gastroenterol. 2008, 14, 3672, doi:10.3748/wjg.14.3672.

48. Grace Nirmala, J.; Evangeline Celsia, S.; Swaminathan, A.; Narendhirakannan, R.T.; Chatterjee, S. Cytotoxicity and apoptotic cell death induced by Vitis vinifera peel and seed extracts in A431 skin cancer cells. Cytotechnology 2018, 70, 537-554, doi:10.1007/s10616-0170125-0.

49. Mahassni, S.H.; Al-Reemi, R.M. Apoptosis and necrosis of human breast cancer cells by an aqueous extract of garden cress (Lepidium sativum) seeds. Saudi J. Biol. Sci. 2013, 20, 131-139, doi:10.1016/j.sjbs.2012.12.002.

50. Moreira, H.; Szyjka, A.; Paliszkiewicz, K.; Barg, E. Prooxidative activity of celastrol induces apoptosis, dna damage, and cell cycle arrest in drug-resistant human colon cancer cells. Oxid. Med. Cell. Longev. 2019, 2019, 1-12, doi:10.1155/2019/6793957.

51. Chen, X.; Song, L.; Hou, Y.; Li, F. Reactive oxygen species induced by icaritin promote DNA strand breaks and apoptosis in human cervical cancer cells. Oncol. Rep. 2019, 41, 765-778, doi:10.3892/or.2018.6864.

52. Augustine, D.; Rao, R.S.; Anbu, J.; Chidambara Murthy, K.N. In vitro cytotoxic and apoptotic induction effect of earthworm coelomic fluid of Eudrilus engeniae, Eisenia foetida, and Perionyx excavatus on human oral squamous cell carcinoma-9 cell line. Toxicol. Reports 
2019, 6, 347-357, doi:10.1016/j.toxrep.2019.04.005.

53. Kuo, P.-L.; Hsu, Y.-L.; Lin, T.-C.; Chang, J.-K.; Lin, C.-C. Induction of cell cycle arrest and apoptosis in human non-small cell lung cancer A549 cells by casuarinin from the bark of Terminalia arjuna Linn. Anticancer. Drugs 2005, 16, 409-415, doi:10.1097/00001813-20050400000007.

54. Atanasov, A.G.; Waltenberger, B.; Pferschy-Wenzig, E.-M.; Linder, T.; Wawrosch, C.; Uhrin, P.; Temml, V.; Wang, L.; Schwaiger, S.; Heiss, E.H.; et al. Discovery and resupply of pharmacologically active plant-derived natural products: A review. Biotechnol. Adv. 2015, 33, 1582-1614, doi:10.1016/j.biotechadv.2015.08.001.

55. Chikezie, P.C.; Ibegbulem, C.O.; Mbagwu, F.N. Bioactive principles from medicinal plants. Res. J. Phytochem. 2015, 9, 88-115, doi:10.3923/rjphyto.2015.88.115.

56. Katiyar, C.; Kanjilal, S.; Gupta, A.; Katiyar, S. Drug discovery from plant sources: An integrated approach. AYU (An Int. Q. J. Res. Ayurveda) 2012, 33, 10, doi:10.4103/09748520.100295.

57. Liu, Z. Preparation of botanical samples for biomedical research. Endocrine, Metab. Immune Disord. Targets 2008, 8, 112-121, doi:10.2174/187153008784534358.

58. Apel, C.; Bignon, J.; Garcia-Alvarez, M.C.; Ciccone, S.; Clerc, P.; Grondin, I.; GirardValenciennes, E.; Smadja, J.; Lopes, P.; Frédérich, M.; et al. N-myristoyltransferases inhibitory activity of ellagitannins from Terminalia bentzoë (L.) L. f. subsp. bentzoë. Fitoterapia 2018, 131, 91-95, doi:10.1016/j.fitote.2018.10.014.

59. Liu, M.; Katerere, D.R.; Gray, A.I.; Seidel, V. Phytochemical and antifungal studies on Terminalia mollis and Terminalia brachystemma. Fitoterapia 2009, 80, 369-373, doi:10.1016/j.fitote.2009.05.006.

60. Tanaka, T.; Nonaka, G.-I.; Nishioka, I. Tannins and related compounds. XLII. Isolation and characterization of four new hydrolyzable tannins, terflavins A and B, tergallagin and tercatain from the leaves of Terminalia catappa L. Chem. Pharm. Bull. (Tokyo). 1986, 34, 10391049, doi:10.1248/cpb.34.1039.

61. Li, J.; Wang, G.; Hou, C.; Li, J.; Luo, Y.; Li, B. Punicalagin and ellagic acid from pomegranate peel induce apoptosis and inhibits proliferation in human HepG2 hepatoma cells through targeting mitochondria. Food Agric. Immunol. 2019, 30, 897-912, doi:10.1080/09540105.2019.1642857.

62. Ceci, C.; Lacal, P.M.; Tentori, L.; De Martino, M.G.; Miano, R.; Graziani, G. Experimental evidence of the antitumor, antimetastatic and antiangiogenic activity of ellagic acid. Nutrients 2018, 10, 1-23, doi:10.3390/nu10111756.

63. Sánchez-Carranza, J.; Alvarez, L.; Marquina-Bahena, S.; Salas-Vidal, E.; Cuevas, V.; Jiménez, E.; Veloz G., R.; Carraz, M.; González-Maya, L. Phenolic compounds isolated from Caesalpinia coriaria induce $S$ and G2/M phase cell cycle arrest differentially and trigger cell death by interfering with microtubule dynamics in cancer cell lines. Molecules 2017, 22, 666, doi:10.3390/molecules22040666.

64. Johnson-ajinwo, O.R.; Richardson, A.; Li, W.-W. Cytotoxic effects of stem bark extracts and pure compounds from Margaritaria discoidea on human ovarian cancer cell lines. Phytomedicine 2015, 22, 1-4, doi:10.1016/j.phymed.2014.09.008.

65. Latté, K.P.; Ferreira, D.; Venkatraman, M.S.; Kolodziej, H. O-galloyl-C-glycosylflavones from Pelargonium reniforme. Phytochemistry 2002, 59, 419-424, doi:10.1016/S0031-9422(01)00403-4.

66. Marzouk, M.S.A.; El-Toumy, S.A.A.; Moharram, F.A. Pharmacologically active ellagitannins from Terminalia myriocarpa. Planta Med. 2002, 68, 523-527, doi:10.1055/s-2002-32549.

67. Yakubu, O.F.; Adebayo, A.H.; Dokunmu, T.M.; Zhang, Y.-J.; Iweala, E.E.J. Cytotoxic effects of compounds isolated from Ricinodendron heudelotii. Molecules 2019, 24, 145, doi:10.3390/molecules24010145. 